\title{
Perceived Promoters of and Barriers to Use of a Learning Management System in an Undergraduate Nursing Program
}

\author{
https://doi.org/10.3991/ijet.v13i02.8085 \\ Fuad Alhosban $(\bowtie)$ \\ Al Khawarizmi International College, Abu Dhabi, United Arab Emirates \\ fuad.alhosbandoutlook.com \\ Samantha Ismaile \\ Princess Nourah bint Abdulrahaman University, Riyadh, Saudi Arabia \\ Higher Colleges of Technology, Abu Dhabi, United Arab Emirates
}

\begin{abstract}
Effective presentation of information is essential in teaching and learning. We assessed the promoters of and barriers to utilization of a learning management system, namely Blackboard* (Blackboard Inc., Washington DC, USA), by undergraduate nursing students. We investigated their utilization of Blackboard and provided recommendations to improve their teaching and learning. We conducted a cross-sectional survey of 304 women in their second to fourth years of study using a validated questionnaire that evaluated their perceptions of Blackboard utilization. Data were collected between January and February 2017 and analyzed using descriptive and comparative statistics. The response rate was $67.5 \%$. The most frequently reported promoters of Blackboard utilization were factors related to obtaining course specifications, materials, and grades (means: $3.54 \pm 1.18,3.54 \pm 1.25$, and $3.55 \pm 1.34$, respectively). The most commonly mentioned barriers to Blackboard utilization were factors related to loss of communication and feedback from educators (mean: $4.21 \pm$ 1.05). Our results revealed that students experiences of using such systems are often negative, especially in terms of communication, interaction, and feedback. Investment in staff training and creation of new roles to monitor, maintain, and audit the quality of such systems are recommended.
\end{abstract}

Keywords-student perception, learning management system, E-learning, nursing.

\section{Introduction}

As the knowledge base of medical education expands, effective presentation of information during teaching and learning becomes an increasingly important consideration. Improvements in technology enhanced learning environments have enabled elearning, which has demonstrated potential to improve the learning process. Elearning allows learners to perform tasks of their choosing, access resources at any 
time, and receive learning support according to their needs, encouraging self-directed learning. [1]

The revolution in technology enhanced learning environments has encouraged educational institutions to adopt and invest in self-directed learning approaches. [2,3] These approaches are delivered by educational software such as learning management systems (LMSs). Defined as software systems created to help educators deliver learning content, facilitate student interactions, and conduct assessments, LMSs are fundamental resources for higher education. [2,4,5] Higher educational institutions worldwide have realized the potential of these systems and invested money, time, and staff in the support of such initiatives. [2,4]

Regardless of the positive attitudes towards such technologies, there is some concern that LMSs are mainly used for distributing teaching materials and course grades rather than for instructional or assessment purposes. [5] One reason for this is the low level of experience of these systems among educators.[5] Moreover, some LMSs do not support interaction or personalization of content, and students prefer to engage with systems offering these features.[6] According to the literature, both students' and lecturers' opinions of LMSs greatly influence the successful adoption of such systems.[3,7]

Although many international studies have shown the advantages of technology enhanced learning environments, their benefits in nursing programs have not been investigated. In this study, we examined the barriers to and promoters of LMS utilization by undergraduate nursing students. Furthermore, we investigated students' perceptions of LMS utilization during study for a bachelor's degree in nursing.

\section{Methods}

\subsection{Study sample}

This study was conducted a public University in Riyadh, Saudi Arabia, in a women-only campus. We distributed a validated self-administered questionnaire to all nursing students in their second to fourth years of study. [3] Data collection took place between January and February 2017. Information sheets were distributed to all participants that explained the aims and background of the study. Participants were also informed that participating in the study was voluntary and that all personal information would remain confidential. Ethical approval was sought from the institutional review board before the study began.

\subsection{Questionnaire}

The validated questionnaire examined students' experiences of using an LMS, namely Blackboard ${ }^{\circ}$ (Bb; Blackboard Inc., Washington DC, USA). The questionnaire consisted of three domains assessed using five-point Likert scales. The first part retrieved demographic data (two items); the second part identified difficulties in $\mathrm{Bb}$ utilization (15 items); and the third part examined students' perceptions of utilizing 
$\mathrm{Bb}$ (10 items). For each item, the score ranged from 5 for "strongly disagree" to 1 for "strongly agree". Approval to use the tool was sought by the authors before starting the study. 3 Descriptive data analysis (mean \pm standard deviation) was performed using SPSS Version 10 (SPSS Inc., Chicago, IL, USA). Associations between categorical outcomes were measured using Pearson's chi-squared test.

\section{Results}

\subsection{Demographic information}

In total, 450 questionnaires were distributed to nursing students. The response rate was $67.5 \%(n=304)$. Of the respondents, $22.5 \%(n=102)$ were in Year 2, 23.3\% $(n$ $=105)$ were in Year 3, and 21.5\% $(\mathrm{n}=97)$ were in Year 4.

Utilization of the Blackboard $®$ learning management system. As shown in Table 1 , the overall mean was $3.8 \pm 12.18$, indicating marked disagreement with the questionnaire items. The highest mean disagreement reported by all students was 4.21 \pm 1.05 for the item "Bb was useful for communication with the instructor". The second highest mean disagreement was $4.12 \pm 1$ for the item "I like to use the multimedia available in $\mathrm{Bb}$ ", followed by $4.1 \pm 1.1$ for the item "Bb was useful for communication with other students".

Conversely, the lowest means were $3.54 \pm 1.18$ and $3.54 \pm 1.25$, indicating strong agreement with items " $\mathrm{Bb}$ was useful for obtaining the course description" and " $\mathrm{Bb}$ was useful for obtaining lecture materials for the course", respectively. These were followed by a mean of $3.55 \pm 1.34$ for the item " $\mathrm{Bb}$ was useful for getting course grades and feedback".

Barriers perceived by undergraduate nurses to Blackboard learning management system use. As presented in Table 2, the overall mean was $2.6 \pm 1.14$, indicating agreement with the questionnaire items. The highest mean disagreement was $4.32 \pm 1.02$ for the item "I have difficulty using a computer". The next highest mean disagreement was $2.91 \pm 1.19$ for the item "I faced technical problems logging on to $\mathrm{Bb}$ ".

In contrast, the lowest mean was $2.15 \pm 1.26$ for the item "user instructions are not clear in Bb", followed by a mean of $2.3 \pm 1.09$ for the item "The $\mathrm{Bb}$ front page is overloaded with information".

The highest percentage agreement was $66.4 \%$ for the item "user instructions are not clear in Bb". Conversely, the highest percentage disagreement was $86.5 \%$ for the item "I have difficulty using a computer".

Further comparative analysis found that female students in their second, third, and fourth years report weak interaction with the faculty in $\mathrm{Bb}(\mathrm{p}=0.0001)$. However, they also reported difficulty using computers $(\mathrm{p}=0.059)$. 
Table 1. Items used to obtain information from undergraduate nursing students about Blackboard utilization.

\begin{tabular}{|c|c|c|c|c|c|c|c|c|c|c|c|c|c|}
\hline \multirow{2}{*}{\begin{tabular}{|l}
\multicolumn{1}{|c}{ Items } \\
$\begin{array}{l}\text { Bb was useful for } \\
\text { obtaining the course } \\
\text { description }\end{array}$
\end{tabular}} & \multirow{2}{*}{\begin{tabular}{|l|}
$n^{*}$ \\
304
\end{tabular}} & \multicolumn{2}{|c|}{$\begin{array}{l}\text { Strongly } \\
\text { agree } \\
n(\%)\end{array}$} & \multicolumn{2}{|c|}{$\begin{array}{l}\text { Agree } \\
n(\%)\end{array}$} & \multicolumn{2}{|c|}{$\begin{array}{l}\text { Don't } \\
\text { know } \\
n(\%)\end{array}$} & \multicolumn{2}{|c|}{$\begin{array}{c}\text { Disagree } \\
n(\%)\end{array}$} & \multicolumn{2}{|c|}{$\begin{array}{c}\text { Strongly } \\
\text { disagree } \\
n(\%)\end{array}$} & \multirow{2}{*}{$\begin{array}{c}\text { Mean } \\
3.54\end{array}$} & \multirow{2}{*}{\begin{tabular}{|l|} 
SD \\
1.18
\end{tabular}} \\
\hline & & 18 & $5.9 \%$ & 39 & $12.8 \%$ & 76 & $25 \%$ & 87 & $28.6 \%$ & 84 & $27.6 \%$ & & \\
\hline $\begin{array}{l}\text { Bb was useful for } \\
\text { obtaining the course } \\
\text { objectives }\end{array}$ & 304 & 11 & $3.6 \%$ & 33 & $10.9 \%$ & 74 & $24.3 \%$ & 92 & $30.3 \%$ & 94 & $30.9 \%$ & 3.71 & 1.15 \\
\hline $\begin{array}{l}\mathrm{Bb} \text { was useful for } \\
\text { obtaining the course } \\
\text { requirements }\end{array}$ & 304 & 8 & $2.6 \%$ & 35 & $11.5 \%$ & 80 & $26.3 \%$ & 82 & $27 \%$ & 99 & $32.6 \%$ & 3.7 & 1.13 \\
\hline $\begin{array}{l}\text { Bb was useful for } \\
\text { obtaining the course } \\
\text { references }\end{array}$ & 304 & 14 & $4.6 \%$ & 29 & $9.5 \%$ & 77 & $25.3 \%$ & 84 & $27.6 \%$ & 100 & $32.9 \%$ & 3.74 & 1.14 \\
\hline $\begin{array}{l}\mathrm{Bb} \text { was useful for } \\
\text { obtaining lecture } \\
\text { materials for the } \\
\text { course }\end{array}$ & 304 & 27 & $8.9 \%$ & 44 & $14.5 \%$ & 50 & $16.4 \%$ & 85 & $28 \%$ & 98 & $32.2 \%$ & 3.54 & 1.25 \\
\hline $\begin{array}{l}\mathrm{Bb} \text { was useful for } \\
\text { communication with } \\
\text { the instructor }\end{array}$ & 304 & 8 & $2.6 \%$ & 15 & $4.9 \%$ & 46 & $15.1 \%$ & 90 & $29.6 \%$ & 145 & $47.7 \%$ & 4.21 & 1.05 \\
\hline $\begin{array}{l}\text { Bb was useful for } \\
\text { communication with } \\
\text { other students }\end{array}$ & 304 & 10 & $3.3 \%$ & 22 & $7.2 \%$ & 40 & $13.2 \%$ & 94 & $30.9 \%$ & 138 & $45.4 \%$ & 4.1 & 1.1 \\
\hline $\begin{array}{l}\text { Bb was useful for e- } \\
\text { mailing the faculty }\end{array}$ & 304 & 17 & $5.6 \%$ & 28 & $9.2 \%$ & 52 & $17.1 \%$ & 77 & $25.3 \%$ & 130 & $42.8 \%$ & 3.88 & 1.21 \\
\hline $\begin{array}{l}\mathrm{Bb} \text { was useful for e- } \\
\text { mailing colleagues }\end{array}$ & 304 & 30 & $9.9 \%$ & 27 & $8.9 \%$ & 41 & $13.5 \%$ & 72 & $23.7 \%$ & 134 & $44.1 \%$ & 3.8 & 1.25 \\
\hline $\begin{array}{l}\text { I like to use the mul- } \\
\text { timedia available in } \\
\mathrm{Bb}\end{array}$ & 304 & 8 & $2.6 \%$ & 9 & $3.0 \%$ & 65 & $21.4 \%$ & 98 & $32.2 \%$ & 124 & $40.8 \%$ & 4.12 & 1 \\
\hline $\begin{array}{l}\text { Bb was useful for } \\
\text { obtaining homework }\end{array}$ & 304 & 20 & $6.6 \%$ & 23 & $7.6 \%$ & 51 & $16.8 \%$ & 90 & $29.6 \%$ & 120 & $39.5 \%$ & 3.84 & 1.02 \\
\hline $\begin{array}{l}\mathrm{Bb} \text { was useful for } \\
\text { submitting homework } \\
\text { and assignments }\end{array}$ & 304 & 22 & $7.2 \%$ & 33 & $10.9 \%$ & 40 & $13.2 \%$ & 75 & $24.7 \%$ & 134 & $44.1 \%$ & 3.86 & 1.34 \\
\hline $\begin{array}{l}\text { Bb was useful for } \\
\text { obtaining the exam } \\
\text { schedule }\end{array}$ & 304 & 18 & $5.9 \%$ & 32 & $10.5 \%$ & 53 & $17.4 \%$ & 76 & $25 \%$ & 125 & $41.1 \%$ & 3.74 & 1.3 \\
\hline $\begin{array}{l}\mathrm{Bb} \text { was useful for } \\
\text { receiving announce- } \\
\text { ments }\end{array}$ & 304 & 30 & $9.9 \%$ & 38 & $12.5 \%$ & 48 & $15.8 \%$ & 88 & $28.9 \%$ & 100 & $32.9 \%$ & 3.62 & 1.28 \\
\hline $\begin{array}{l}\mathrm{Bb} \text { was useful for } \\
\text { getting course grades } \\
\text { and feedback }\end{array}$ & 304 & 30 & $9.9 \%$ & 34 & $11.2 \%$ & 65 & $21.4 \%$ & 70 & $23.0 \%$ & 105 & $34.5 \%$ & 3.55 & 1.34 \\
\hline Average score & 304 & 18.07 & 0.06 & 29.4 & 0.1 & 57.2 & 0.19 & 84 & 0.28 & 115.33 & 0.38 & 3.8 & 1.18 \\
\hline
\end{tabular}

$\mathrm{SD}$, standard deviation; Bb, Blackboard®. 
Table 2. Perceptions of nursing undergraduates of Blackboard ${ }^{\circ}$ utilization.

\begin{tabular}{|c|c|c|c|c|c|c|c|c|c|c|c|c|c|}
\hline \multirow{2}{*}{\begin{tabular}{|c|} 
Items \\
Lack of training in $\mathrm{Bb}$ \\
\end{tabular}} & \multirow{2}{*}{\begin{tabular}{|l|}
$n^{*}$ \\
304 \\
\end{tabular}} & \multicolumn{2}{|c|}{$\begin{array}{l}\text { Strongly } \\
\text { agree } \\
n(\%)\end{array}$} & \multicolumn{2}{|c|}{$\begin{array}{l}\text { Agree } \\
n(\%)\end{array}$} & \multicolumn{2}{|c|}{$\begin{array}{l}\text { Don't } \\
\text { know } \\
n(\%)\end{array}$} & \multicolumn{2}{|c|}{$\begin{array}{c}\text { Disagree } \\
n(\%)\end{array}$} & \multicolumn{2}{|c|}{$\begin{array}{c}\text { Strongly } \\
\text { disagree } \\
n(\%)\end{array}$} & \multirow{2}{*}{\begin{tabular}{|l|} 
Mean \\
2.31 \\
\end{tabular}} & \multirow{2}{*}{$\begin{array}{l}\text { SD } \\
1.1\end{array}$} \\
\hline & & 89 & $29.3 \%$ & 101 & $33.2 \%$ & 75 & $24.7 \%$ & 23 & $7.6 \%$ & 16 & $5.3 \%$ & & \\
\hline $\begin{array}{l}\mathrm{Bb} \text { increases the curricu- } \\
\text { lum burden }\end{array}$ & 304 & 40 & $13.2 \%$ & 61 & $20.1 \%$ & 122 & $40.1 \%$ & 58 & $19.1 \%$ & 23 & $7.6 \%$ & 2.9 & 1.12 \\
\hline $\mathrm{Bb}$ use is time consuming & 304 & 41 & $.5 \%$ & 72 & $23.7 \%$ & 80 & $6.3 \%$ & 81 & $26.6 \%$ & 30 & $9.9 \%$ & 2.9 & 1.1 \\
\hline $\begin{array}{l}\text { Limitations of } \mathrm{Bb} \text { ser- } \\
\text { vices }\end{array}$ & 304 & 78 & $25.7 \%$ & 86 & $28.3 \%$ & 114 & $37.5 \%$ & 17 & $5.6 \%$ & 9 & $3 \%$ & 2.38 & 1.2 \\
\hline instructions are not & 304 & 108 & $5.5 \%$ & 94 & $30.9 \%$ & 68 & $22.4 \%$ & 23 & $7.6 \%$ & 11 & $3.6 \%$ & 2.15 & 1.26 \\
\hline $\begin{array}{l}\text { The } \mathrm{Bb} \text { front page is } \\
\text { overloaded with infor- } \\
\text { mation }\end{array}$ & 304 & 65 & $21.4 \%$ & 94 & $30.9 \%$ & 90 & $29.6 \%$ & 43 & $14.1 \%$ & 12 & $3.9 \%$ & 2.3 & 1.09 \\
\hline $\begin{array}{l}\text { Weak } \\
\text { facul }\end{array}$ & 304 & 100 & $32.9 \%$ & 84 & $27.6 \%$ & 100 & $32.9 \%$ & 10 & $3.3 \%$ & 10 & $3.3 \%$ & 2.33 & 1.12 \\
\hline $\begin{array}{l}\text { I faced technical problems } \\
\text { logging on to } \mathrm{Bb}\end{array}$ & 304 & 45 & $14.8 \%$ & 50 & $16.4 \%$ & 114 & $37.5 \%$ & 70 & $23 \%$ & 25 & $8.2 \%$ & 2.91 & 1.19 \\
\hline $\begin{array}{l}\text { Technical difficulties with } \\
\mathrm{Bb}\end{array}$ & 304 & 59 & $19.4 \%$ & 70 & $23 \%$ & 140 & $46.1 \%$ & 20 & $6.6 \%$ & 15 & $4.9 \%$ & 2.41 & 1.2 \\
\hline $\begin{array}{l}\text { I have difficulty using a } \\
\text { computer }\end{array}$ & 304 & 3 & $1 \%$ & 8 & $2.6 \%$ & 30 & $9.9 \%$ & 108 & $35.5 \%$ & 155 & $51 \%$ & 4.32 & 1.02 \\
\hline Average score & 304 & 62.8 & 0.21 & 72 & 0.24 & 93.3 & 0.31 & 45.3 & 0.15 & 30.6 & 0.1 & 2.69 & 1.14 \\
\hline
\end{tabular}

$\mathrm{SD}$, standard deviation; Bb, Blackboard®.

\section{Discussion}

Technology enhanced learning delivered by LMSs has demonstrated potential to enhance self-directed learning by students. [8] Interestingly, our results showed the opposite. The expected benefits of LMS utilization were not perceived by our students. This finding is consistent with that of another study performed in Saudi Arabia involving medical students. [3] Our students expressed a negative attitude toward the implementation of an LMS in their study program. Although our students reported proficiency in computer use, they found the LMS difficult to use. However, a recent study undertaken in Saudi Arabia confirmed that students value LMSs, and that LMSs improve the learning process. [9]

Our students reported a lack of communication with their teachers and with other students. Thus, the benefits of the LMS as a collaborative learning environment were not perceived. This may have been caused by a lack of student training in use of the LMS or failure of the educators to successfully implement the LMS. However, the students professed good computer skills. This calls into question the educators' abilities to implement LMS objectives. Our results suggest that, although higher educational institutions are investing in LMSs, they lack qualified and trained teaching staff who understand the concept of self-directed learning and how to achieve it by successful exploitation of LMS resources. Therefore, educators need to take a more ac- 
tive role in developing LMS content. Alternatively, college administrations must create new roles, such as e-learning managers or directors of medical education, to monitor, maintain, and audit LMSs. [8]

The strongest promoter of $\mathrm{Bb}$ utilization perceived by our students was its ability to provide course information, materials, and grades. This result was similar to that of many other studies on the benefits of LMSs. [9,10] In contrast, the strongest barriers to $\mathrm{Bb}$ use perceived by our students were the lack of clear instructions on how to use the interface and that the front page was overloaded with information. Educators may believe that filling the front page with material makes it easier for students to access and find information. Overloading may also result from educators' lack of experience in setting up their course page. Whatever the cause, an overloaded first page may confer a higher cognitive load on students, consequently discouraging them from interacting with learning materials. [1]

Nursing students reported that they rarely experience difficulty using computers, yet they faced technical problems logging into $\mathrm{Bb}$. This was confirmed by a recent study, which reported that nursing students demonstrate informatics competencies, including computer skills. The study explained that the recent cohort of undergraduate students, termed the "net generation", are aware of technologies and communication innovations. [11] This awareness gives them the requisite computer skills to use LMSs.

When we compared the responses of nursing students in their third and fourth years, the results confirmed that our students faced problems interacting with their educators as well as their peers. Again, this indicates that educators did not exploit the communication and interactivity features supported by the LMS as a result of either a lack of awareness of these features or a lack of proper training on LMS content development. In order to enhance self-directed learning among students, it is crucial for feedback, interaction, and communication to occur within the e-learning environment. In particular, nursing students are educated to value communication, interaction and feedback as they are key concepts of patient care and safety. [12-14] The negative perception of communication via the LMS among our students may have compromised their learning and prevented them from achieving the course objectives. Therefore, to enhance self-directed learning through LMS use, it is essential to create an interactive learning environment.

In summary, this study highlights the barriers to and promoters of LMS utilization in a nursing program. The most commonly mentioned barriers to LMS utilization were related to the lack of interaction, communication, and feedback from educators via the LMS. The most commonly mentioned promoters of LMS utilization were related to obtaining course specifications, materials, and grades.

This study was conducted at one educational institution in women alone, which may represent a limitation with regard to the generalizability of the data. We recommend further study on the faculty perception of $\mathrm{Bb}$ utilization. Indeed, adding a qualitative investigation on the perception of $\mathrm{Bb}$ utilization among students and educators will enrich the results by exploring their feelings, insights, and thoughts. [15] 


\section{Conclusion}

The results of this study highlight the promoters of and barriers to LMS utilization by female nursing students. We found that accessing course specifications, materials, and grades were the most commonly reported promoters of LMS utilization by nursing students. Conversely, a lack of interaction, communication, and feedback were the most commonly reported barriers to LMS utilization. Interestingly, although nursing students reported competency in computer use, they still found the LMS difficult to use in a beneficial way.

The implications and recommendations of this study are that higher educational institutions should invest in LMS environments, but that they should also invest in staff training and create new roles to monitor, maintain, and audit the quality of LMS content. The content must also be mapped to the program and course learning outcomes to achieve the maximum benefits of such environments.

\section{Acknowledgment}

The researchers would like to thank all students who took part in this study at Princess Nourah bint Abdulrahman University.

\section{$7 \quad$ References}

[1] Alhosban F, Burd L. Aural instruction with visualization in E-Learning. Paper presented at: Frontiers in Education Conference, 2012. https://doi.org/10.1109/FIE.2012.6462290

[2] Subramanian GS, Perumal V. MOODLE Based E-Learning Resource for Revising Clinical Anatomy: An Inexpensive and Interactive Supplement for Physiotherapy Students. Int J Physiother. 2016;3(4):409-414. https://doi.org/10.15621/ijphy/2016/v3i4/111044

[3] Al-Drees A, Khalil MS, Meo SA, Abdulghani HM. Utilization of blackboard among undergraduate medical students: Where we are from the reality? Journal of Taibah University Medical Sciences. 2015;10(1):16-20. https://doi.org/10.1016/j.jtumed.2014.07.002

[4] Chipps J, Kerr J, Brysiewicz P, Walters F. A survey of university students' perceptions of learning management systems in a low-resource setting using a technology acceptance model. Comput Inform Nurs. 2015;33(2):71-77. https://doi.org/10.1097/CIN.0000000 000000123

[5] Woods R, Baker JD, Hopper D. Hybrid structures: Faculty use and perception of webbased courseware as a supplement to face-to-face instruction. The Internet and Higher Education. 2004;7(4):281-297. https://doi.org/10.1016/j.iheduc.2004.09.002

[6] Muñoz DC, Ortiz A, González C, López DM, Blobel B. Effective e-learning for health professional and medical students: the experience with SIAS-Intelligent Tutoring System. Stud Health Technol Inform. 2010;156:89-102.

[7] Webster J, Hackley P. Teaching effectiveness in technology-mediated distance learning. The Academy of Management Journal. 1997;40(6):1282-1309. https://doi.org/10.2307/ $\underline{257034}$ 
[8] Padilla-Meléndez A, del Águila-Obra AR, Garrido-Moreno A. Using MOODLE in Teaching-Learning Processes in Business Management: The New Profile of EHEA Student. Educación XX1. 2014;18(1):125-146. https://doi.org/10.5944/educxx1.18.1.12314

[9] Alhussain T. Measuring the Impact of the Blackboard System on Blended Learning Students. IJACSA. 2017;8(3):297-301. https://doi.org/10.14569/IJACSA.2017.080341

[10] Chawdhry, A., Paullet, K., Benjamin, D. (2011). Assessing Blackboard: Improving Online Instructional Delivery. Information Systems Education Journal, 9(4) pp 20-26.

[11] 11Alhosban F, Ismaile S, Hawamdeh S, Househ M. Assessment of Informatics Competencies Among Nursing Students: The Net Generation. Comput Inform Nurs. 2017. In press

[12] Allari S, Ismaile S, and Househ S. Professional Values Among Female Nursing Students in Saudi Arabia. Stud Health Technol Inform, 2017; (238):261-264.

[13] Ismaile S. Perceived Clinical Stressors among Saudi Nursing Students. Open Journal of Nursing. 2017;17(04):463-472. https://doi.org/10.4236/ojn.2017.74036

[14] Alshehri H, Ismaile S. Nurses experience of communication with palliative patients in critical care unit: Saudi experience. International Journal of Advanced Nursing Studies. 2016;5(2):102-108. https://doi.org/10.14419/ijans.v5i2.6171

[15] Straus A, Corbin J. Basics of Qualitative Research. Grounded Theory Procedures and Techniques. California: SAGE Publications, Inc; 1990.

\section{Authors}

Dr. Fuad Alhosban is Assistant Professor in Computer Science, Department of Information Technology, Al Khawarizmi International College, Abu Dhabi, the United Arab of Emirates. His area of research interest includes Technology Enhanced Learning, Health Informatics and Visualisation. Dr Alhosban was also managing the activates of the Research Chair of Health Informatics and Promotion RCHIP.ORG in $\mathrm{KSU}$, Riyadh, KSA. Dr. Alhosban have a PhD in Computing Technologies from Durham University-UK, and MSc degree in Computer Science from Coventry University-UK. (fuad.alhosban@outlook.com)

Dr. Samantha Ismaile is a Fellow of Higher Education Academy (FHEA) in the UK. Dr Ismaile have a PhD degree in Health Studies (Medical Education, Leadership and Administration in Nursing) and MSc degree in Medical Education. Both higher degrees were obtained from Durham University-UK. Currently, she is an assistant professor and the Director for E-learning unit at the College of Nursing, and previously the Director of Nursing program. Her area of research and interest includes Health policy, Medical Education, e-Health, e-Learning, Health Informatics, Leadership and Management, Patient Safety and Quality of Care. Dr. Ismaile has been awarded several excellence prizes and awards for her education, research and projects. (Samantha.ismaile@ymail.com)

Article submitted 08 December 2017. Resubmitted 22 January 2018. Final acceptance 04 February 2018. Final version published as submitted by the authors. 